Jurnal

Kardiologi Indonesia

J Kardiol Indones. 2012;33:202-4

ISSN 0I 26/3773

\title{
Elevasi Segmen ST Varian Normal
}

Yoga Yuniadi

Elevasi segmen ST selalu menimbulkan dugaan adanya infark miokard akut. Walaupun sebenarnya tidak semua elevasi segmen ST berkaitan dengan adanya oklusi arteri koroner karena ada gambaran elevasi segmen ST yang hanya merupakan varian normal. Tulisan ini akan menyegarkan kembali pengetahuan tentang elevasi segmen ST varian normal.

Pertama, penting diingatkan kembali cara menentukan elevasi atau depresi segmen ST yaitu dengan membandingkan posisi segmen ST terhadap segmen PR yang medahuluinya. Perhatikan posisi titik
J yaitu pangkal segmen ST terhadap posisi segmen PR. Bila titik J berada di atas segmen PR maka dikatakan elevasi segmen ST, sebaliknya bila posisi titik J di bawah segmen PR maka dikatakan depresi segmen ST. Jangan menentukan adanya elevasi atau depresi segmen ST dengan membandingkanya terhadap segmen TP.

Gambar 1 merupakan contoh suatu elevasi segmen ST yang normal. ${ }^{1}$ Perhatikan adanya elevasi segmen ST yang jelas di sadapan V1 sampai V5 dan penting dicatat morfologi elevasi segmen ST terlihat agak cekung (concave). Sudah sejak lama diketahui bahwa

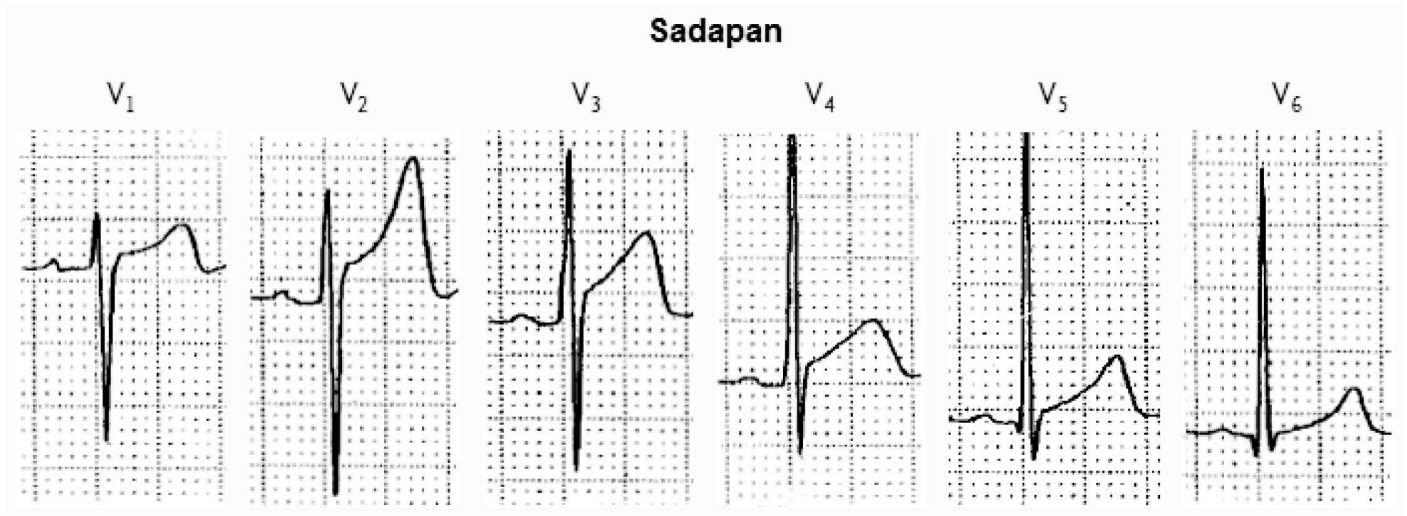

Gambar 1. EKG dari suatu elevasi segmen ST yang normal. Dimodifikasi dari kepustakaan no. 1.

\section{Alamat korespondensi:}

Dr. dr. Yoga Yuniadi, SpJP, Divisi Aritmia, Departemen Kardiologi dan Kedokteran Vaskuler FKUI dan Pusat Jantung Nasional Harapan, Kita, JI S Parman Kav 87 Jakarta I I420, E-mail: yogayun@yahoo.com 
elevasi segmen ST antara 1-3 mm pada satu atau lebih sadapan prekordial dapat ditemukan pada 9193 persen oranglaki-laki sehat yang berusia antara 16 hingga 58 tahun. ${ }^{2,3}$ Elevasi segmen ST yang normal ini terutama terlihat jelas di sadapan V2.Kejadian elevasi segmen ST menurun dengan bertambahnya usia, yaitu menjadi sekitar 30 persen pada usia lebih dari 75 tahun. Pada wanita sehat hanya sekitar 20 persen yang mempunyai elevasi segmen ST antara 1-3 mm, tetapi kejadianya tidak menurun dengan bertambahnya usia. ${ }^{1}$ Berdasarkan temuan di atas dapat dikatakan bahwa mayoritas laki-laki memiliki gambaran elevasi segmen ST $1 \mathrm{~mm}$ atau lebih di sadapan prekordial, artinya hal itu merupakan gambaran normal bukan varian normal. Gambaran yang demikian disebut sebagai pola EKG laki-laki, sedangkan elevasi segmen ST yang kurang dari $1 \mathrm{~mm}$ disebut pola EKG perempuan. ${ }^{3}$ Pola EKG tersebut harus cekung. Terdapat hubungan antara kedalaman gelombang $S$ dengan elevasi segmen ST terutama pada pasien dengan hipertrofi ventrikel kiri, yaitu makin dalam gelombang $S$ maka makin tinggi elevasi segmen $S T .^{1}$

Pola EKG laki-laki sering menyesatkan dalam diagnosis infark miokard akut dengan elevasi segmen ST (IMAEST), apalagi bila terdapat gambaran QS di V1-V3 yang sering ditemukan bila aksis QRS lebih posterior pada pasien hipertrofi ventrikel kiri. Oleh karena itudiagnosis IMAEST tidak boleh hanya didasarkan pada gambaran EKG semata. Kriteria gejala klinis yang khas yaitu angina pektoris dan peningkatan biomarker yang spesifik merupakan kriteria yang juga diperlukan untuk menegakkan IMAEST ${ }^{4}$ pada EKG dengan pola laki-laki.

Repolarisasi dini yang ditandai dengan elevasi segmen ST di sadapan mid-prekordial merupakan suatu varian normal. Pada suatu repolarisasi dini, umumnya sadapan V4 menunjukkan elevasi segmen ST yang paling kentara, ditandai juga dengan adanya takik pada titik J. Gambaran elevasi segmen ST terlihat cekung. Gelombang T biasanya positif tinggi.

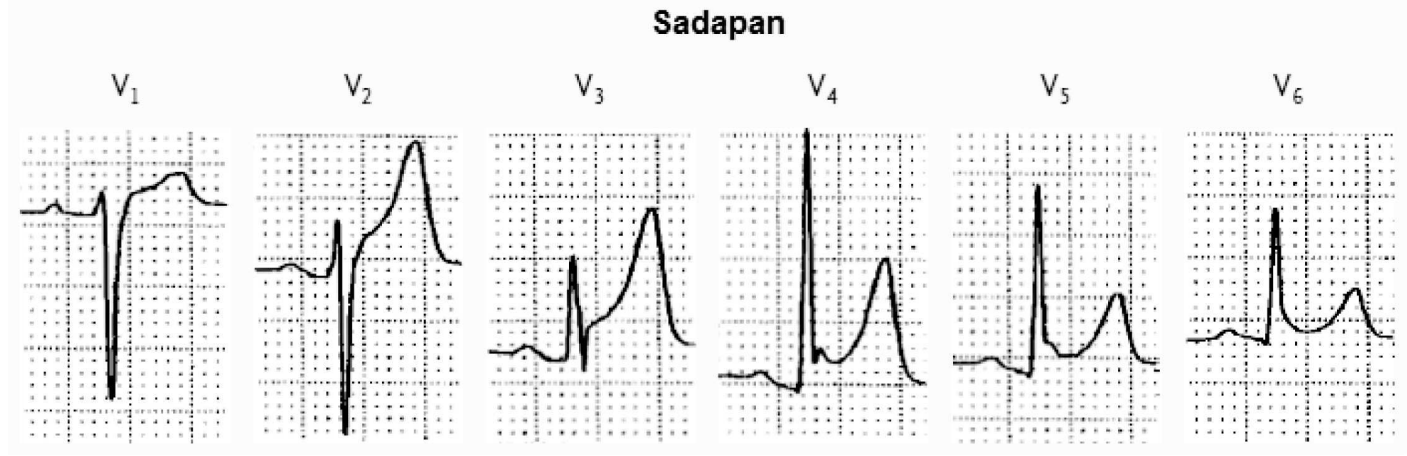

Gambar 2. Repolarisasi dini.

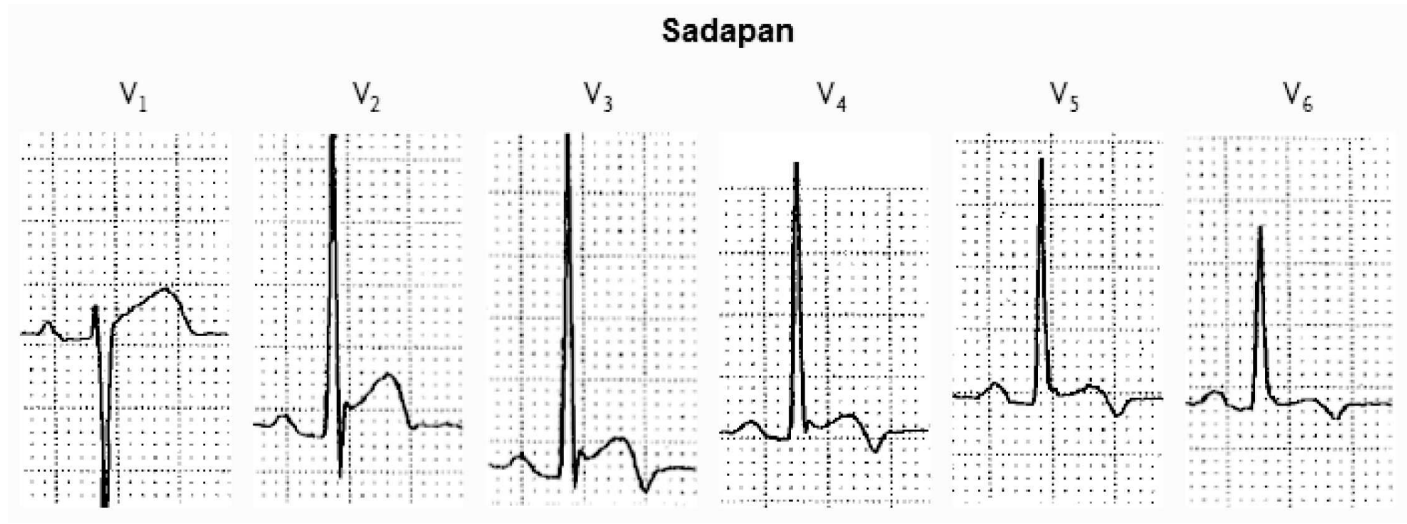

Gambar 3. Repolarisasi dini dan gelombang $\mathrm{T}$ inversi yang merupakan varial normal. Perhatikan interval QT yang pendek dan segmen ST yang cekung. 
Bila repolarisasi dini melibatkan sadapan ekstremitas, biasanya elevasi segmen ST paling jelas di sadapan II dengan gambaran resiprokal berupa depresisegmen ST di sadapan aVR. Repolarisasi dini di sadapan inferior dengan elevasi titik J 0.1 $\mathrm{mV}$ atau lebih berkaitan dengan peningkatan kematian kardiovaskular. ${ }^{5}$ Repolarisasi dini dapat juga melibatkan jaringan atrium yang ditandai dengan depresi segmen PR.

Elevasi segmen ST pada sadapan mid-prekordial dapat disertai dengan inversi gelombang $\mathrm{T}$ seperti terlihat pada gambar 3. Hal ini merupakan suatu gambaran EKG varian normal, yaitu suatu kombinasi antara repolarisasi dini dengan pola gelombang T-juvenile yang menetap. Gambaran EKG inipun menyulitkan dalam diagnosis karena sangat mirip dengan infark miokard akut. Oleh karena itu sekali lagi jangan hanya mengandalkan EKG tetapi pemeriksaan yang lebih komprehensif diperlukan untuk menegakkan diagnosis yang benar. Sebagai alat bantu, mengukur interval QT dapat membedakan pola varian normal di atas dari infark miokard akut, yaitu didapatkan interval QT yang pendek pada pola varian normal. Selain itu, segmen ST pada varian normal cekung berbeda dengan infark miokard yang cembung. ${ }^{1}$ Walaupun secara gambaran EKG, pola EKG laki-laki sebagaimana diuraikan di atas memenuhi syarat sebagai kandidat pemberian terapi trombolitik ${ }^{6}$, tetapi tentu dibutuhkan penegakan diagnosis infark miokard yang benar sebelum memutuskan pemberian terapi trombolitik. Berdasarkan panduan terbaru kriteria diagnosis ingfark miokard akut universal, suatu perubahan segmen ST dan gelombang $\mathrm{T}$ yang baru atau yang dianggap baru dapat didiagnosis sebagai infark miokard akut bila disertai peningkatan troponin jantung setidaknya satu tingkat di atas batas atas (upper reference limit) persentil ke 99.7

Jadi dapat disimpulkan bahwa elevasi segmen ST di sadapan prekordial dapat atau bahkan sering merupakan suatu gambaran normal atau varian normal. Jangan mendiagnosis infark miokard akut apalagi memberikan terapi trombolitik hanya atas dasar EKG sesaat.Serial EKG yang menunjukkan evolusi infark miokard akut lebih bernilai diagnostik. Infark miokard akut adalah kejadian nekrosis miokard pada situasi klinis dengan iskemia miokard sehingga perlu dibuktikan dengan peningkatan bermakna nilai troponin jantung.

\section{Daftar Pustaka}

1. Wang K, Asinger RW, Marriott HJ. ST-segment elevation in conditions other than acute myocardial infarction. $N$ Engl J Med. 2003;349(22):2128-2135.

2. Hiss RG, Lamb LE, Allen MF. Electrocardiographic findings in 67,375 asymptomatic subjects. Am J Cardiol. 1960;6:200-231.

3. Surawicz B, Parikh SR. Prevalence of male and female patterns of early ventricular repolarization in the normal ECG of males and females from childhood to old age. J Am Coll Cardiol. 2002;40(10):1870-1876.

4. Anonymous. Nomenclature and criteria for diagnosis of ischemic heart disease. Report of the Joint International Society and Federation of Cardiology/World Health Organization task force on standardization of clinical nomenclature. Circulation. 1979;59(3):607-609.

5. Tikkanen JT, Anttonen O, Junttila MJ, Aro AL, Kerola T, Rissanen HA, Reunanen A, Huikuri HV. Long-term outcome associated with early repolarization on electrocardiography. $N$ Engl J Med. 2009;361(26):2529-2537.

6. Ryan TJ, Anderson JL, Antman EM, Braniff BA, Brooks NH, Califf RM, Hillis LD, Hiratzka LF, Rapaport E, Riegel BJ, Russell RO, Smith EE, Jr., Weaver WD. ACC/AHA guidelines for the management of patients with acute myocardial infarction. A report of the American College of Cardiology/American Heart Association Task Force on Practice Guidelines (Committee on Management of Acute Myocardial Infarction). J Am Coll Cardiol. 1996;28(5):1328-1428.

7. Thygesen K, Alpert JS, Jaffe AS, Simoons ML, Chaitman BR, White HD, Katus HA, Apple FS, Lindahl B, Morrow DA, Clemmensen PM, Johanson P, Hod H, Underwood R, Bax JJ, Bonow RO, Pinto F, Gibbons RJ, Fox KA, Atar D, Newby LK, Galvani M, Hamm CW, Uretsky BF, Gabriel Steg P, Wijns W, Bassand JP, Menasche P, Ravkilde J, Ohman EM, Antman EM, Wallentin LC, Armstrong PW, Januzzi JL, Nieminen MS, Gheorghiade M, Filippatos G, Luepker RV, Fortmann SP, Rosamond WD, Levy D, Wood D, Smith SC, Hu D, LopezSendon JL, Robertson RM, Weaver D, Tendera M, Bove AA, Parkhomenko AN, Vasilieva EJ, Mendis S, Baumgartner H, Ceconi C, Dean V, Deaton C, Fagard R, Funck-Brentano C, Hasdai D, Hoes A, Kirchhof P, Knuuti J, Kolh P, McDonagh T, Moulin C, Popescu BA, Reiner Z, Sechtem U, Sirnes PA, Torbicki A, Vahanian A, Windecker S, Morais J, Aguiar C, Almahmeed W, Arnar DO, Barili F, Bloch KD, Bolger AF, Botker HE, Bozkurt B, Bugiardini R, Cannon C, de Lemos J, Eberli FR, Escobar E, Hlatky M, James S, Kern KB, Moliterno DJ, Mueller C, Neskovic AN, Pieske BM, Schulman SP, Storey RF, Taubert KA, Vranckx P, Wagner DR. Third universal definition of myocardial infarction. Eur Heart J.33(20):2551-2567. 